\title{
BENTUK DAN FUNGSI KATEGORI FATIS DALAM KOMUNIKASI LISAN BAHASA MELAYU DIALEK SUNGAI ROKAN SERTA IMPLIKASI TERHADAP PENDIDIKAN
}

\author{
Oleh \\ Gunawan \\ STKIP Rokania
}

Email: gunawanrohul@gmail.com

\begin{tabular}{ll}
\hline Article History \\
\hline Received & : December 2019 \\
Accepted & :January \\
& 2020 \\
Published & : February 2020
\end{tabular}

\section{Keywords}

Bentuk, fungsi, kategori fatis, komunikasi lisan, Bahasa Melayu

\begin{abstract}
The method used in this study is a qualitative approach with descriptive research types. The research method is aimed at obtaining a description of the use of disclosure in the communi- cation of the Rokan River Malay Language. Forms of categorization of languages: Malay, Sungai Rokan dialect, District of regency, Regency of Hulutiri, consisting of 25 particles, 20 in the form of words, 15 in the form of form and 6 in the form of a square and a sentence The number of syrups will be added to follow the development and the need for discussion of the Spread community itself. The function of the anti-religious in the language The Malay Sungai Rokan dialect is not only to start, greet, confirm and maintain, in this thesis, researchers find 10 functions that are commonly used by the community of Sungai Rokan, including; pharynx functions to start, maintain, confirm, terminate, affirm, convince, admonish, praise, and fear / bully. From a group of forms, fatism in the language of living in the Sungai Rokan is very dominant using the particle, and functions, the dominant use of which is the function and ridicule. Based on the data analysis, it can be concluded that the Malay language of the Rokan River Dialect has 60 forms of phisic categories and the phisic form of the particle is phatic which is often used. In terms of function, the Malay language of the Rokan River Dialect has 10 phatic functions and the dominant one is the affirmative and mocking function.
\end{abstract}


penggunaan pengungkapan dalam komunikasi Bahasa Melayu Sungai Rokan. Bentuk kategorisasi bahasa: Bahasa Melayu, dialek Sungai Rokan, Distrik Kabupaten, Kabupaten Hulutiri, yang terdiri dari 25 partikel, 20 dalam bentuk kata-kata, 15 dalam bentuk kata-kata, 15 dalam bentuk bentuk dan 6 dalam bentuk kuadrat dan kalimat Jumlah sirup akan ditambahkan untuk mengikuti perkembangan dan kebutuhan untuk diskusi tentang komunitas Spread itu sendiri Fungsi anti-agama dalam bahasa Dialek Sungai Rokan Melayu tidak hanya untuk mulai, sapa, konfirmasi dan pertahankan, dalam tesis ini, para peneliti menemukan 10 fungsi yang umum digunakan oleh komunitas Sungai Rokan, termasuk; fungsi faring untuk memulai, memelihara, mengkonfirmasi, mengakhiri, menegaskan, meyakinkan, meyakinkan, admo nish, pujian, dan ketakutan / pengganggu. Dari sekelompok bentuk, fatisme dalam bahasa yang tinggal di Sungai Rokan sangat dominan menggunakan partikel, dan fungsinya, yang dominan digunakan adalah fungsi dan ejekan. Berdasarkan analisis data, dapat disimpulkan bahwa bahasa Melayu Dialek Sungai Rokan memiliki 60 bentuk kategori fisik dan bentuk fisik partikelnya adalah phatic yang sering digunakan. Dari segi fungsi, bahasa Melayu Dialek Sungai Rokan memiliki 10 fungsi phatic dan yang dominan adalah fungsi afirmatif dan mengejek. 


\section{A. Pendahuluan}

Salah satu unsur yang paling penting dalam kehidupan manusia adalah bahasa. Bahasa adalah ucapan pikiran dan perasaan manusia yang teratur dengan memakai alat bunyi. Definisi tersebut menjelaskan bahwa bahasa mencakup segenap cara penyampaian gagasan, ide, dan buah pikiran yang disampaikan dalam bentuk bunyi. Bahasa dapat diartikan sebagai cara manusia untuk menyatakan maksud, buah pikiran dan perasaannya kepada orang lain.

Manusia sebagai makhluk sosial, selalu berkomunikasi dan berinteraksi dengan orang lain. Komunikasi, interaksi dan segala macam kegiatan akan lumpuh tanpa adanya bahasa. Bahasa senantiasa berada dalam konteks sosial penuturnya. Dengan demikian, bahasa disebut sebagai sarana terpenting dalam komunikasi baik secara lisan ataupun tulisan.

Sebagai alat yang penting dalam komunikasi, bahasa dalam interaksi antarpeserta tutur berfungsi sebagai alat untuk membuka saluran komunikasi. Bahasa sebagai alat bagi manusia untuk menjalin komunikasi dan keakrabaan dengan lingkungan manusia lainnya.
Bahasa disampaikan agar tidak terjalin pembicaraan yang komunikatif.

Sebagai sistem lambang bunyi yang arbitrer, bahasa juga digunakan oleh suatu masyarakat untuk bekerja sama, berkomunikasi, dan mengidentifikasi diri. Sebagai suatu sistem, bahasa terbentuk oleh suatu aturan, kaidah dan pola tertentu, baik dalam tata bunyi, tata bentuk kata, maupun tata kalimat. Apabila aturan, kaidah, atau pola ini dilanggar, maka komunikasi dapat terganggu.

Bahasa juga berhubungan erat dengan kebudayaan. Kebudayaan merupakan suatu sistem komunikasi, dan bahasa mempunyai makna hanya dalam kebudayaan sebagai wadahnya. Demikian erat hubungan bahasa dengan kebudayaan, maka bahasa sering dijadikan tujuan untuk dapat mengerti lebih mendalam pola-pola dan nilai-nilai suatu masyarakat.

Bahasa menjadi pilihan utama manusia saat berkomunikasi. Hakikat komunikasi adalah peristiwa sosial, yaitu peristiwa yang terjadi ketika manusia berinteraksi dengan manusia yang lain. Dalam berkomunikasi sering kali ditemukan ungkapan-ungkapan yang maknanya tidak sesuai dengan makna kata yang membentuknya. Maksud pengutaraan 
ungkapan itu biasanya ditujukan untuk membuka, mengawali, mempertegas ungkapan, memperhalus tuturan, menyapa dan sebagainya. Bentuk-bentuk linguistik yang dipakai dalam tuturan tersebut disebut fungsi fatis. Fatis dipahami sebagai suatu jenis ujaran yang mengikat satu kesatuan yang diciptakan dengan pertukaran kata-kata belaka. Fatis juga berfungsi untuk memulai, mempertahankan, atau mengukuhkan pembicaraan antara penutur dan lawan penuturnya. Hal itu menunjukkan bahwa kategori fatis berada dalam keanggotaan kelas kata yang tidak bermakna apa-apa dalam komunikasi, melainkan memenuhi suatu fungsi sosial serta membuat bahasa yang disampaikan lebih komunikatif.

Fatis biasanya hadir dalam konteks dialog atau wawancara. Sebagian besar dari kategori fatis merupakan ciri ragam lisan. Oleh karena itu, pada umumnya merupakan ragam non-standar maka banyak ditemukan dalam dialek regional atau mengandung unsur kedaerahan.

Demikian juga dengan bahasa Melayu Riau Dialek Sungai Rokan, yakni sebuah dialek yang digunakan oleh masyarakat Sungai Rokan untuk berkomunikasi dalam kehidupan sehari- hari. Dewasa ini, keaslian dialek Sungai Rokan sudah mulai sulit dipertahankan karena masalah banyaknya orang Sungai Rokan yang menikah dengan orang luar daerahnya, sehingga dialek Sungai Rokan juga mendapat pengaruh oleh bahasa daerah lain seperti bahasa Batak, bahasa Minangkabau, dan bahasa Jawa. Padahal, bahasa daerah merupakan sebuah kekayaan bangsa. Ia menjadi bukti adanya peradaban, seni dan budaya yang diwariskan secara turun-temurun.

Banyak hal yang bisa diteliti dari bahasa daerah Dialek Sungai Rokan, salah satunya tentang fatis. Dalam berbagai kegiatan komunikasi di tengah masyarakat pengguna bahasa Melayu Dialek Sungai Rokan, terlihat betapa kedudukan fatis menjadi sangat istimewa karena fatis dapat membentuk dan menjaga kontak atau hubungan sosial dalam komunikasi.

Beberapa penelitian tentang fatis memberikan gambaran bahwa bentuk ungkapan fatis bertujuan untuk mengungkapkan kesantunan dan sosiabilitas. kategori fatis merupakan kategori yang sering muncul dalam komunikasi lisan secara pragmatik adat dan tata krama. Faizah juga menjelaskan bahwa fatis bukan hanya kumpulan kata, 
frasa, atau kalimat yang tidak bermakna, melainkan secara pragmatik memiliki fungsi untuk menjaga kestabilan komunikasi masyarakat. Demikian juga dengan kategori fatis dalam bahasa Melayu Dialek Sungai Rokan, menjadi objek yang patut dikaji secara mendalam karena kategori fatis bahasa Sungai Rokan sangat dominan dipakai dalam komunikasi masyarakat setiap hari.

Fatis bahasa Melayu Dialek Sungai Rokan sangat kaya terutama pada bentuk partikel. Dari segi fungsi bahasa Melayu Dialek Sungai Rokan, terdapat sepuluh fungsi fatis yang selalu dipakai. Penelitian terhadap bahasa Melayu Dialek Sungai Rokan ini masih langka sehingga penulis tertarik untuk melestarikan dan mengembangkan bahasa Melayu dialek Sungai Rokan ini sejajar dengan bahasa daerah lainnya. Penelitian tentang komunikasi fatis dalam masyarakat Melayu ini belum pernah ada yang meneliti. Selain itu, jika dikaji lebih lanjut kategori fatis merupakan hal subtansial dalam kedududukannya dengan kelas kata lainnya.

Fatis menjadi ciri khas gaya bertutur lisan masyarakat, terutama di tengah masyarakat Sungai Rokan. Fatis banyak ditemukan dalam bahasa lisan berbentuk dialog atau wacana. Bahasa Melayu Riau Dialek Sungai Rokan adalah bahasa yang digunakan oleh masyarakat Sungai Rokan dan mempunyai ciri khas tersendiri. Sungai Rokan sendiri adalah nama lain yang disematkan pada kabupaten yang bernama Rokan Hulu. Di tengah kabupaten ini mengalir sungai bernama Sungai Rokan yang panjangnya kurang lebih $100 \mathrm{~km}$. Ungkapan fatis dalam bahasa Melayu Dialek Sungai Rokan cukup banyak dijumpai. Ungkapan fatis yang digunakan berfungsi untuk menyampaikan maksud dan keinginan.

Berdasarkan latar belakang masalah, maka penelitian ini difokuskan pada fungsi kategori komunikasi fatis bahasa Melayu Dialek Sungai Rokan yang terdiri dari bentuk kategori fatis, fungsi kategori fatis dan makna fatis.

Adapun tujuan yang ingin dicapai dalam penelitian ini adalah untuk menganalisis: (1) Mendeskripsikan bentuk kategori fatis dalam komunikasi lisan bahasa Melayu Sungai Rokan; (2) Mendeskripsikan fungsi kategori fatis dalam komunikasi lisan Bahasa Melayu Dialek Sungai Rokan. 
Dalam berkomunikasi ditemukan ungkapan-ungkapan yang maknanya tidak sesuai dengan makna kata yang membentuknya. Maksud pengutaraan ungkapan itu biasanya ditujukan untuk membuka, mengawali, mempertegas ungkapan, memperhalus tuturan, menyapa dan sebagainya. Bentuk linguistik yang dipakai dalam tuturan tersebut dinamakan fungsi fatis. Interaksi yang ada dalam wadah komunikasi, ditandai oleh bentukbentuk fatis disebut komunikasi fatis.

Teori yang dipakai dalam penelitian ini adalah Kridalaksana (1994:47) mengatakan bahwa fatis termasuk dalam pembagian tiga belas kelas kata bahasa Indonesia, verba, adjektiva, nomina, promomina, numeralia, adverbia, interogativa, demonstrativa, artikula, preposisi, konjungsi, interjeksi, dan kategori fatis.

Banyak ahli yang telah mendefinisikan tentang kategori fatis. Kategori Fatis ini pertama kali dikemukakan oleh Malinowski dalam Sutami (2004:51) dengan istilah Phatic Communion yaitu suatu jenis ujaran yang mengikat satu kesatuan yang diciptakan dengan pertukaran kata-kata belaka. Kategori fatis pertama sekali diperkenalkan oleh Kridalaksana di Indonesia pada tahun 1986.

Kategori fatis menurut Kridalaksana (1994:14) adalah ungkapan/konstituen yang bertugas memulai, mempertahankan, atau mengukuhkan komunikasi antara pembicara dan lawan bicara. Kelas kata ini bersifat komunikatif artinya berfungsi untuk memelihara hubungan sosial di antara penutur dan lawan tutur. Dengan kata lain, ungkapan fatis dapat menghidupkan dialog sehingga memperlancar komunikasi. Ungkapanungkapan yang muncul dalam komunikasi fatis tidak untuk memberi tekanan pada isi informasi melainkan memiliki fungsi sosial untuk memelihara hubungan sosial di antara penutur dan lawan tutur.

Pendapat yang sama juga diungkapkan Kridalaksana (1990:114) bahwa kategori fatis adalah kategori yang memulai, mempertahankan, atau mengukuhkan pembicaraan antara penutur dan lawan penuturnya. Hal itu menunjukkan bahwa kategori fatis berada dalam keanggotaan kelas kata yang tidak bermakna apa-apa dalam komunikasi, melainkan memenuhi suatu fungsi sosial serta membuat bahasa yang disampaikan lebih komunikatif.

ISSN. 2527-6018 
Selanjutnya Lavinson dalam Sutami (2004:51) mengungkapkan bahwa fungsi fatis itu membentuk dan menjaga kontak atau hubungan sosial dalam komunikasi. Pendapat ini sejalan dengan Leech (1993:223) yang menyatakan bahwa fatis digunakan untuk menjaga sopan santun dengan prilaku berbicara. Sutami (2004:50) menyatakan bahwa kategori fatis merupakan kata gramatikal ataupun kata fungsional dengan ciri-ciri sebagai berikut: (a) tidak memiliki akar yang jelas, (2) tidak memiliki otonomi semantis, (c) merupakan kata fungsional. Selanjutnya Simatupang dalam Sutami (2004:203) menyatakan bahwa ungkapan fatis mempunyai makna context sensitive atau terikat konteks.

Widjono (2007:139) menyatakan bahwa fatis berfungsi untuk memulai, mempertahankan, atau mengukuhkan pembicaraan. Jenis kata ini lazim digunakan dalam dialog atau wawancara. Misalnya, ah, ayo, kok, mari, nah dan yah. Tujuan dari komunikasi fatis (phatic communication) dalam komunikasi di tengah masyarakat pada umumnya dimaksudkan untuk menimbulkan kesenangan. Komunikasi ini menunjukkan hubungan akrab dan menyenangkan.
Kridaklaksana (1990:114) memberikan penjelasan terperinci tentang fungsi kategori fatis, antara lain: (1) untuk memulai komunikasi atau perbualan, (2) untuk mengekalkan komunikasi, (3) untuk menghentikan komunikasi, dan (4) untuk menegaskan komunikasi atau perbuatan. Secara umum dapat dikatakan bahwa kategori fatis merupakan kategori yang komunikatif, karena kategori fatis tidak dapat dimaknai secara harfiah, melainkan tergantung pada situasi komunikasi tertentu dan langsung dalam proses tuturan. Fatis menjadi ciri khas gaya bertutur lisan masyarakat, terutama di tengah masyarakat Sungai Rokan. Fatis banyak ditemukan dalam bahasa lisan berbentuk dialog atau wacana. Bahasa Melayu Riau Dialek Sungai Rokan adalah bahasa yang digunakan oleh masyarakat Sungai Rokan dan mempunyai ciri khas tersendiri. Bahasa sebagai alat komunikasi berperan penting bagi perkembangan intelektual, sosial, dan emosional. Pentingnya bahasa sebagai alat komunikasi dapat dilihat dari setiap aktivitas manusia yang selalu menggunakan bahasa sebagai wahana pokoknya.

Ungkapan fatis dalam bahasa Melayu Dialek Sungai Rokan cukup banyak 
dijumpai. Ungkapan fatis yang digunakan berfungsi untuk menyampaikan berbagai macam maksud dan keinginan. Sebagai contoh, dalam komunikasi masyarakat sehari-hari akan sering terdengar ungkapan sebagai berikut; mo, inyo yang muantakan barang tu tadi! (dia yang mengantar barang itu tadi!). o, iyo tenyo, lah patuik telah! ( Itu memang sudah sepatutnya!). Pada kalimat di atas fungsi fatis mo sebagai kalimat mempertegas bahwa pekerjaan itu memang sudah selayaknya dilakukan. Atau pada ungkapan berikut; lai kan tamat bang taun ikonyo? (mungkinkah kamu bisa tamat tahun ini?) lai ntong! (tentu!). ntong merupakan kata fatis yang berfungsi sebagai kata yang mempertegas dan meyakinkan lawan komunikasi. Begitu pentingnya fatis dalam komunikasi lisan masyarakat Sungai Rokan, sehingga hampir dalam setiap interaksi komunikasinya selalu ada ungkapan fatis.

\section{B. Metode Penelitian}

Penelitian ini menggunakan metode kualitatif dengan pendekatan deskriptif. Menurut Moleong (2012:6), penelitian kualitatif adalah penelitian yang bermaksud untuk memahami fenomena yang dialami oleh subjek penelitian misalnya perilaku, persepsi, motivasi, tindakan. Secara holistik, dan dengan cara deskripsi dalam bentuk kata-kata dan bahasa, pada suatu konteks khusus yang alamiah dan dengan memanfaatkan berbagai metode alamiah.

Penelitian ini dilakukan di Sungai Rokan, Kabupaten Roka Hulu FebruariJuli 2018. Hal yang diteliti dalam penelitian ini adalah bentuk dan fungsi kategori fatis dalam komunikasi lisan bahasa Melayu Dialek Sungai Rokan. Kehadiran peneliti terlibat secara langsung dengan informan penelitian.

Landasan untuk menentukan informan dalam penelitian ini adalah pendapat dari Reniwati, menurutnya (2009: 36-37) informan adalah orang yang akan memberikan data penelitian. Informan akan memberikan informasi kebahasaan yang dicari oleh si peneliti. Tanpa informan, penelitian tidak dapat dilakukan. Selanjutnya, Nadra dan Reniwati (2009: 37) mengatakan syarat informan adalah: (1) berusia 40-60 tahun, (2) berpendidikan tidak terlalu tinggi, (3) berasal dari desa atau daerah penelitian, (4) lahir dan dibesarkan serta menikah dengan orang yang berasal dari daerah penelitian, (5) 
memiliki alat ucap yang sempurna dan lengkap.

Data dalam penelitian ini berupa ujaran kategori fatis yang didapatkan dari hasil wawancara, dan hasil temuantemuan tentang fatis saat proses pelaksanaan penelitian. Sumber data pada penelitian ini adalah tuturan masyarakat asli Sungai Rokan. Masyarakat Sungai Rokan adaah masyarakat yang mendiami kawasan di sepanjang Sungai Rokan, mulai dari kabupaten Rokan Hulu, hingga ke kabupaten Rokan Hilir. Namun yang menjadi sumber hanyalah masyarakat Rokan Hulu saja, khususnya di kecamatan Rambah, Pasir Pengaraian.

Langkah-langkah yang dilakukan peneliti dalam mengumpulkan data ini adalah sebagai berikut; Pertama, Teknik rekaman merupakan teknik pokok yang dilakukan dalam penelitian ini. Upaya yang dilakukan adalah dengan mengajukan pertanyaan dan merangsang responden untuk menjawab semua pertanyaan serta mencatat semua informasi yang dibutuhkan dengan benar. Kedua Elisitasi langsung (tanpa penerjemahan), peneliti adalah orang yang memahami bahasa Melayu Riau Dialek Sungai Rokan, maka teknik ini dapat dimanfaatkan sebaik-baiknya untuk melengkapi data penelitian. Ketiga, Pencatatan, hal ini dilakukan untuk lebih memperjelas data yang diperoleh dari informan. Keempat, Inventaris pengujian data dalam format pengumpulan data.

\section{Hasil Penelitian dan Pembahasan}

Fatis adalah kategori kata yang hanya memiliki fungsi sosial dan tidak memiliki fungsi makna dalam penyampaian informasi. Bentuk fatis hadir dalam bahasa lisan non standar. Bentuknya terdapat di awal, tengah maupun akhir kalimat. Bentuknya mirip dengan interjeksi, namun tidak dapat dimasukkan ke dalam kelas kata interjeksi, karena interjeksi bersifat emotif sedangkan fatis bersifat komunikatif.

Pertama, pada umumnya fatis merupakan suatu gagasan yang tidak untuk memberikan informasi atau ide. Sebagaimana yang diterangkan oleh Malinowsky (1923:314) dalam tulisannya The Problem of Meaning in Primitive Language dengan istilah " Phatic Communion" yakni suatu jenis ujaran yang mengikat satu kesatuan, diwujudkan dengan pertukaran kata-kata. Fatis bertujuan untuk membangun dan juga 
menjaga keakraban. Disisi lain fatis juga menjadi bagian dari kesantunan penutur kepada lawan tuturnya. Beberapa fungsi fatis yang selalu digunakan menurut Kridalaksana ialah untuk memulai, mempertahankan, atau mengukuhkan komunikasi antara pembicara dan lawan bicara (2000:114). Namun dalam penelitian ini peneliti menemukan sepuluh fungsi fatis bahasa Melayu Dialek Sungai Rokan, Kabupaten Rokan Hulu, yaitu; fungsi memulai, mempertahankan, mengukuhkan, mengakhiri, menegaskan, meyakinkan, menasihati, mengejek, memuji dan menakuti. Dari data tuturan yang telah dikumpulkan, peneliti mengklasifikasi tuturan yang mengandung fatis fungsi memulai 17 data, mempertahankan 19 data, mengukuhkan 18 data, mengakhiri 17 data, menegaskan 29 data, meyakinkan 20 data, menasihati 18 data, mengejek 22 data, memuji 19 data, menakuti 9 data.

Bentuk tuturan fatis dapat berupa pertanyaan-pertanyaan yang tidak informatif dalam komunikasi, akan tetapi pertanyaan tersebut sangat penting dilakukan demi menjaga komunikasi supaya terus berlangsung (Kridalaksana 2000, 114). Pada intinya fatis adalah bentuk tindak tutur yang fungsinya untuk menjalin hubungan sosial. Dari data penelitian yang penulis temukan ada empat kategori fatis dalam bahasa Melayu Dialek Sungai Rokan, kabupaten Rokan Hulu.

Berdasarkan teori Kridalaksana hanya membagi tiga bentuk kategori fatis, yaitu kategori partikel, kategori kata, dan kategori frasa. Namun, di dalam penelitian ini, penulis menemukan satu bentuk lagi yaitu kategori kalimat. Jadi dalam bahasa Melayu Dialek Sungai Rokan ada empat kategori fatis yang peneliti temukan. Berikut pemaparan bentuk dan fungsi kategori fatis bahasa Melayu Dialek Sungai Rokan.

Kedua, bentuk kategori fatis bahasa Melayu Dialek Sungai Rokan terdiri dari bentuk partikel, kata, frasa dan kalimat. Dalam data penelitian ini, terdapat 25 fatis bentuk partikel yang ditemukan dalam 100 tuturan. 5 tuturan mengandung partikel pun, 5 partikel leh, 5 partikel dih, 5 partikel nyeh, 5 partikel pan, 5 partikel na, 5 partikel neh, 5 partikel lah, 5 parrtikel $d o, 5$ partikel $m o, 5$ partikel $t i$, 5 partikel nyo, 5 patikel tu, 5 partikel jo, 5 partikel ha, 5 partikel e'eh, 2 partikel moh, 3 partikel noh, 2 partikel yoh, 2 partikel 
yek, 4 partikel wo, 4 partikel hoi, 3 partikel dek, 3 partikel $a h$, dan 2 partikel teh.

Fatis dalam bentuk kategori kata ditemukan sebanyak 20 fatis dalam 42 tuturan masyarakat Melayu Sungai Rokan. 2 tuturan mengandung fatis kata kotoih, 2 kata haram, 2 kata prenyo, 2 kata fatis kosan, 2 kata fatis sungoh, 2 kata fatis penyoh, 2 kata fatis sampuk, 2 kata fatis aci, 2 kata fatis nyenyo, 2 kata opak, 2 kata fatis karam, 2 kata fatis sudah, 2 kata fatis caduk, 2 kata fatis cakuk, 2 kata fatis pusek, 2 kata fatis posoik, 2 kata fatis pungah, 2 kata fatis cunek, 2 kata fatis buhene, 2 kata fatis suai, 2 kata fatis jaek, dan 2 kata fatis taek.

Dari kategori bentuk frasa, ditemukan 15 fatis dalam 30 tuturan masyarakat Sungai Rokan. 2 frasa fatis kosannyo ti, 2 ha jek, 2 betu ti ajaknyo, 2 no teleh, 2 no tedo, 2 nyeku na, 2 nyo abang na, 2 mo betu tenyo, 2 pungah halun, 2 klea sunsang, 2 apo koba, 2 trimu kasih, 2 apo cito, 2 pusek paja ko, dan 2 palo abah bang tu.

Kategori fatis bentuk klausa dan kalimat ditemukan 6 fatis dalam 12 tuturan masyarakat Sungai Rokan. 2 fatis tuhan kan memonten, 2 fatis no kan tido cala wak do wo, 2 fatis nyo abang na, nyo aku, 2 fatis poi nyo abang mo poi, dan 2 fatis palih alahnyo ti. Dari keseluruhan bentuk kategori fatis di atas, fatis yang paling dominan dipakai di tengah masyarakat Melayu Dialek Sungai Rokan adalah fatis bentuk partikel. Dan dari keseluruhan fatis bentuk partikel tersebut, yang selalu dipakai adalah partikel leh, do, ti dan nyo.

Ada hal unik dalam fatis tuturan masyarakat Rambah, yaitu fatis yang hanya berbentuk bunyi dari satu huruf yang dominan. Fatis ini mirip dengan partikel, tapi bukan partikel utuh. Seperti partikel fatis e'eh atau mmmmm (bunyi huruf M). Partikel e'eh dibaca dengan menekan bunyi e, dan menipiskan bunyi eh. Berfungsi merespon tuturan lawan bicara. Begitupun dengan partikel mmmmm juga berfungsi sama dengan partikel e'eh. Ada pula partikel yang diulang-ulang lafalnya dan juga berfungsi sama dengan dua partikel di atas. Partikel $j O ́$ adalah partikel yang diulang-ulang lafalnya. Fungsinya untuk memastikan seseorang sudah memahami apa yang disampaikan lawan bicaranya.

Fatis bentuk klausa dan kalimat tidak terlalu banyak dijumpai, setidaknya ada enam kalimat yang memang selalu 
dituturkan oleh masyarakat. Namun, yang menarik dari fatis bentuk kalimat ini adalah, bisa jadi jumlah kalimat fatis lebih banyak dari jumlah kategori fatis yang lain, karena bentuk kalimat fatis ini tidak ada yang tetap. Kalimat fatis bisa terjadi akibat dari respon penutur terhadap tuturan yang ia dengar dari lawan bicara. Si pendengar atau lawan bicara cukup hanya memberikan kalimat yang sama dalam merespon ucapan lawan bicaranya. Contohnya seseorang yang mengucapkan 1 kalimat kepada lawan bicaranya dan lawan bicara tersebut cukup menjawab dengan kalimat yang sama. Misal, poi wak ke rumah si anu tu beko yoh! ( nanti kita pergi ke rumah si Anu ya). sorah abang, poi wak ke rumah si anu tu beko mo poi (terserah kamu saja). Pada hakikatnya lawan bicara cukup menjawab dengan kata iya, atau tidak. namun ia menjawab dengan kalimat yang sama dengan lawan bicaranya. Maka fungsi kalimat yang diucapkannya berubah menjadi fatis.

Ketiga, pembahasan mengenai fungsi fatis bahasa Melayu Dialek Sungai Rokan harus selalu dikaitkan dengan konteks tuturan itu saat dilafalkan oleh penuturnya. Maka pembahasan ini berdasarkan dari data tuturan di tengah masyarakat berdasarkan konteks bahasa itu dituturkan. Konteks tuturan menjadi hal yang wajib dibicarakan karena dalam penelitian ini akan dijumpai bentuk kategori fatis yang sama, namun fungsinya menjadi berbeda karena konteksnya berbeda. Hal yang menyebabkan fatis tersebut menjadi sama atau pun berbeda fungsinya karena letak posisi fatis di dalam tuturan dan juga konteks tuturan itu dilafalkan. Maksud konteks di sini adalah waktu, suasa atau keadaan saat tuturan itu dilafalkan di tengah masyarakat.

Dalam data yang peneliti kumpulkan berdasarkan konteks tuturan di tengah masyarakat Melayu Sungai Rokan, ada 17 tuturan mengandung fatis yang berfungsi untuk memulai, 19 tuturan mengandung fatis yang berfungsi untuk mempertahankan, 18 tuturan mengandung fatis yang berfungsi untuk mengukuhkan, 17 tuturan yang mengandung fatis untuk mengakhiri, 29 tuturan yang mengandung fatis untuk menegaskan, 20 tuturan mengandung fatis yang berfungsi untuk meyakinkan, 18 tuturan mengandung fatis yang berfungsi untuk menasihati, 22 tuturan mengandung fatis yang berfungsi untuk mengejek, 19 tuturan mengandung fatis yang berfungsi untuk memuji, dan 9 
tuturan mengandung fatis yang berfungsi untuk menakuti.

Fatis yang paling dominan digunakan dalam bahasa Melayu Riau Dialek Sungai Rokan adalah fatis fungsi menegaskan. Selanjutnya fatis yang sering digunakan adalah fatis fungsi mengejek. Hal ini mudah dijelaskan karena karakter orang Sungai Rokan adalah suka bercanda, cemeeh, atau saling ejek dengan sesama. Bahkan ada pepatah tempatan yang menyatakan bahwa, "kalau tak pencemeeh, bukanlah orang Sungai Rokan”. Begitu kuatnya karakter ini melekat pada masyarakat Sungai Rokan sehingga tergambar jelas dalam penelitian ini. Dan yang paling jarang digunakan adalah fatis dengan fungsi menakuti/ menggertak.

Empat, pada bagian ini, perlu dibahas mengenai konteks dan letak atau posisi fatis di dalam tuturan bahasa masyarakat Melayu Riau Dialek Sungai Rokan, alasannya karena ada beberapa fatis yang sama, namun fungsinya berbeda karena pengaruh konteks dan letak fatis tersebut. Begitu pula sebaliknya ada fatis yang berbeda namun punya fungsi yang sama karena pengaruh keduanya. Konteks adalah hal yang tidak bisa diabaikan dalam penelitian bahasa sebagai alat komunikasi terutama tentang penelitian fatis. Ada dua macam konteks untuk memahami makna fatis bahasa Melayu Dialek Sungai Rokan, yaitu konteks bahasa dan konteks non bahasa (konteks situasi). Konteks yang dimaksud adalah pengetahuan latar yang diketahui bersama oleh penutur dan petutur. Sedangkan konteks merupakan hal yang dinamis, bukan statis, yang harus dipahami sebagai lingkungan yang senantiasa berubah, yang memungkinkan para partisipan dalam proses komunikasi dapat berinteraksi sehingga ekspresi linguistik yang digunakan dapat dipahami dengan baik. Beberapa fatis di bawah ini menjelaskan pengaruh konteks dan posisi letaknya di dalam tuturan;

Partikel na, berfungsi untuk memulai komunikasi. Contoh kalimat "betu na diek" (begini dik). Posisinya fatis berada di tengah kalimat. Tanpa partikel na, kalimat akan tetap berfungsi sebagai mana mestinya, namun dengan adanya partikel $n a$, informasi yang akan diberikan dari seseorang kepada lawan bicaranya menjadi penting dan perlu untuk disimak. Letak partikel ini dalam tuturan masyarakat Melayu Sungai Rokan selalu berada di tengah atau di akhir. Letaknya di tengah atau di akhir kalimat tidak akan 
mengubah maksud dan fungsi kalimat. Partikel $n a$ ini selalu digunakan dalam konteks tertentu, seperti menginginkan sesuatu, atau merayu. Ketika komunikasi kaku karena sifat segan kepada seseorang, maka partikel $n a$ bisa menjadi alternatif untuk memulai percakapan.

Partikel $t i$, contoh dalam kalimat, abang ti yang mencari sengke tu? (Kamu yang cari perkara itu?). Partikel ti, berfungsi untuk memulai komunikasi. Posisinya berada di tengah kalimat. Tanpa partikel $t i$, kalimat akan tetap berfungsi sebagai mana mestinya, namun dengan adanya partikel $t i$ tuturan dinilai sebagai sesuatu yang penting. Posisinya mesti berada di tengah kalimat, karena jika diletakkan di awal atau di akhir, partikel $t i$ tidak berfungsi sama sekali dan membuat kalimat akan terdengar aneh. Aneh yang dimaksud dalam penjelasan ini adalah di luar dari kebiasaan tuturan orang Melayu Sungai Rokan.

Kelima, orang Sungai Rokan merupakan bagian dari bangsa Melayu. Disebut sebagai orang Sungai Rokan karena bermastautin di sepanjang sungai bernama Sungai Rokan atau Sungai Batang Lubuh. Meskipun bagian dari bangsa Melayu, tapi orang Sungai Rokan punya perbedaan dialek sendiri dalam soal bahasa. Orang Sungai Rokan memakai bahasa Melayu dialek Sungai Rokan dengan dominan memainkan bunyi-bunyi O pada kata-kata tertentu sehingga menjadi ciri khas bahasanya sendiri, bukan bunyi-bunyi $\mathrm{E}$ tipis sebagai mana umumnya dilafalkan orang Melayu kebanyakan. Contoh kata kemano, dimano, iko, indo, inyo, dan sebagainya, bukan kemane, siape, die dan lain-lain. Ada yang beranggapan bahwa bahasa Melayu Sungai Rokan berasal dari bahasa Minangkabau atau sebaliknya. Hal ini belum dapat dibuktikan kebenarannya. Namun bila dikatakan mirip atau punya kesamaan, hal ini boleh dibenarkan. Dalilnya karena orang Minangkabau adalah salah satu dari Bangsa Melayu, sama perihalnya dengan Orang Sungai Rokan. Akan hal perbedaannya tentu sangat berbeda. Dalam bidal orang tua-tua dikatakan, lain padang, lain ilalang, lain lubuk lain ikannya. Lain tempat lain pula bahasa dan adat istiadatnya.

Keberadaan dialek Sungai Rokan memang seakan mendapat pengaruh dari dialek bahasa perantau Batak, Mandailing, Jawa, Minangkabau, atau Sunda begitu juga sebaliknya. Namun pengaruh itu 
hanya berkisar pada dialeknya saja, tidak pada kosa kata yang dipakai. Namun ada yang menjadi spesial dilidah asli Orang Sungai Rokan, yaitu lafal huruf $o$, (dilafalkan antara bunyi $\mathrm{O}$ dan $\mathrm{U}$ dengan meninggi). Di lidah Orang Sungai Rokan, hal ini dapat membedakan antara Orang Sungai Rokan asli tempatan atau perantau. Karena umumnya di lidah orang non Melayu Sungai Rokan, lafal huruf tersebut akan tetap dibunyikan sebagai huruf $\mathrm{O}$ pada umumnya. Contoh kata giló tidak dibaca gilo (gila). Begitupun dengan kata guló untuk gulo (gula).

Pengaruh itu juga berdampak terhadap bahasa anak-anak yang diajarkan oleh orang tuanya berbahasa Indonesia di rumah. Hal ini sangat berdampak terhadap dialek Orang Sungai Rokan di masa mendatang. Perlunya adanya keseimbangan dalam mengajarkan anakanak mencintai bahasa daerahnya dan tidak meninggalkan bahasa Indonesia adalah bekal keberlangsungan da keberadaan bahasa daerah manapun dan kapanpun.

\section{Simpulan dan Saran}

Bentuk dan fungsi Fatis bahasa Melayu Dialek Sungai Rokan dapat disumpulkan:

1. Bentuk kategori fatis bahasa Melayu Dialek Sungai Rokan Kecamatan Rambah kabupaten Rokan Hulu terdiri dari 25 partikel fatis, 20 dalam bentuk kata, 15 dalam bentuk frasa dan 6 dalam bentuk kalusa dan kalimat. Jumlah ini bisa jadi akan bertambah mengikut perkembangan dan kebutuhan bahasa pada masyarakat Rambah sendiri.

2. Fungsi kategori fatis dalam bahasa Melayu Dialek Sungai Rokan tidak hanya untuk memulai, menyapa, mengukuhkan dan mempertahankan, namun dalam tesis ini, peneliti menemukan 10 fungsi kategori fatis yang biasa dipakai oleh masyarakat Melayu Sungai Rokan, diantaranya; fatis berfungsi untuk memulai, mempertahankan, mengukuhkan, mengakhiri, penegasan, meyakinkan, menasihati, mengejek, memuji, dan menakuti/ menggertak. 
Hasil penelitian ini berimplikasi positif untuk memperkuat sikap penerimaan masyarakat terhadap kehadiran bahasa Sungai Rokan sebagai jati diri atau identitas. Selain itu hasil penelitian ini memberikan andil demi terwujudnya dan lestarinya adat budaya di Sungai Rokan.

Penelitian ini memberikan stimulus dan sumbangan kepada pemerintah setempat dan khusunya terhadap dunia pendidikan terutama bagi guru bahasa Indonesia. Penelitian ini juga dapat menjadi pedoman sebagai upaya meningkatkan kompetensi mengajar di kelas terutama untuk siswa yang menggunakan bahasa ibu yakni bahasa daerah Sungai Rokan.

Disisi lain, jika dicermati simpulan penelitian ini mempunyai implikasi pada pendidikan bahasa dan sastra bagi guru dan murid-murid di sekolah karena bahasa daerah tidak bisa dilepaskan dari dunia pendidikan di sekolah. Adakalanya guru harus menerangkan pelajaran dengan berbahasa daerah agar tujuan pembelajaran sampai kepada murid. Kategori fatis membantu guru untuk memudahkan interaksi guru dengan murid terutama bagi murid yang belum lancer menggunakan bahasa Indonesia. Implikasi lain adalah bagi masyarakat Sungai Rokan untuk lebih memperkuat serta mempertahankan bahasa dan sastra daerah sendiri sebagai identitasnya, karena sesungguhnya bahasa Sungai Rokan adalah bahasa yang digunakan oleh penuturnya dan bahasa yang terbuka untuk pengembangnnya.

\section{Daftar Pustaka}

Kridalaksana, H. (1990). Kelas Kata dalam Bahasa Indonesia. Jakarta: PT Gramedia.

Kridalaksana, H. (1994). Kelas Kata dalam Bahasa Indonesia. Jakarta: PT Gramedia Pustaka.

Leech, G. (1993.). Prinsip-prinsip Pragmatik. Jakarta: UI Press.

Malinowski. (1923). Bronisla W Malinowski And Linguistic Pragmatics. London: Trubner.

Reniwati, N. d. (2009). Dialektologi; Teori dan Metode. Padang: Elmatera Publishing.

Sutami, H. (2005). Fungsi Komunikasi Fatis dalam Bahasa Mandarin. Depok: Pusat Leksikologi dan Leksikografi: Universitas Indonesia. 